\title{
IAMJ
}

INTERNATIONAL

AYURVEDIC

MEDICAL JOURNAL

ISSN: 2320-5091

Impact Factor: 6.719

\section{A REVIEW ARTICLE ON DIET IN GRAHANI ROGA}

\author{
Khushboo Bhardwaj' ${ }^{1}$ D. K Goyal' ${ }^{2}$, Arun Kumar Sharma ${ }^{3}$ \\ ${ }^{1}$ M.D. (Final Year). PG Dept. Of Kaya Chikitsa Gurukul Campus, UAU Haridwar, Uttarakhand, India \\ ${ }^{2}$ Professor PG Dept. Of Kaya Chikitsa Gurukul Campus, UAU, Haridwar, Uttarakhand, India \\ ${ }^{3}$ Associate Professor PG Dept. Of Kaya Chikitsa Gurukul Campus, UAU, Haridwar, Uttarakhand, India
}

Corresponding Author: bhardwajkhushboo73@gmail.com

\section{https://doi.org/10.46607/iamj3408122020}

(Published online: December 2020)

Open Access

(C) International Ayurvedic Medical Journal, India 2020

Article Received: 16/12/2020 - Peer Reviewed: 17/12/2020 - Accepted for Publication: 18/12/2020

D) Check for updates

\section{ABSTRACT}

The Grahani is the leading disorder of the digestive system. Due to various etiological factors of Grahani Roga, the Grahani becomes impaired as a result of Dusti or vitiation of Pachakagni and Saman Vayu. The Vaisamya at Saman Vayu causes the hyper motility of gut resulting in frequent evacuation of the bowel, which one large and hard or liquid. The principle of diet for all types of Grahani is boost the Agni and reduce the Ama with the help of Ahara Dravyas, which included mainly Kashaya, Madhura and Katu in Rasa; Laghu, Ruksha, Grahee, Deepana and Pachana in Guna; Ushna in Veerya and Katu or Madhura in Vipaka. The diet regime suggested by Ayurveda helps in stimulation of Agni, which supports the digestion of food of appropriate quality, taken in required quantity and in right time for cure of Grahani Roga or Irritable Bowel Syndrome.

Keywords: Grahani, Agni, Saman Vayu, Diet.

\section{INTRODUCTION}

Acharya Charaka has described that the Jatharagni (Annasya Pakta) is the chief among all the categories of Agni, as Bhutagni and Dhatvagni are dependent upon it. Aggravation or diminution of Jatharagni results in the aggravation or diminution of respective Bhutagni as well as Dhatvagni. Therefore, the condition of Jatharagni should be suitably and carefully maintained, because life and strength of 
individual are dependent upon it. Mandagni (weak digestive power) is a root cause of Amadosha (undigested food) and it is the crucial factor for manifestation of most of the diseases.

The 28 Ahara Dravyas of various classes can be suggested for Grahani patients. Thus, we can resume the bowel habit to normal, improve the overall nutritional status of patients and can prevent or reduce the complications of IBS with the help of Ayurvedic principles of diet. Chaturvidha Ahara Dravyas of six Rasas Kashaya Madhura, Amla, Lavana, Katu, Tikta, and go to transform into three kinds of Rasas Madhura, Amla and Katu and become fit for metabolic activity (reaction) by the action of Jatharagni. Grahani (duodenum and the upper part of small intestine), which is the site of Agni (enzymes responsible for digestion and metabolism), is so called because of its power to restrain (the downward movement) of undigested food and retains food till it is fully digested.

The function of Agni in general- Charka says that the life span, complexion, vitality good health enthusiasm, plumpness, glow, vital essence, lusture, heat the life breaths are derived from the thermo - genetic process (life in the body). When this fire is extinguished man dies, when a man maintains samagni, He lives long in good health. When it is deranged, he begins to ill, therefore the thermal function said to the main stay of life.

Now-a-day's unwholesome food habits and a lot of changes in lifestyle, mental stress, anxiety, grief, lead to gastric upset (Agnimandhya), which is the root cause for the manifestation of various diseases like Atisar, Pravahika, Amlapitta, Grahani.

\section{Aim of Diet: -}

There is nothing else except diet for sustaining the life of living beings. One is capable to make man diseasefree only with the congenial diet. It is also true that in both the conditions, i.e. health and disease, the wholesomeness and the unwholesomeness is a prime factor to be thought about, as without proper diet, the use of any drug is futile.

The aim of diet in person suffering from Grahani can be stated as.

1. An enhancement in the Agni can improve the functioning of Grahani.

2. The reduction in Amadosha with the help of Deepana (appetizer), Pachana (digestant) and Laghu (easy to digest) Dravyas.

3. Correction in bowel habit in terms of volume and consistency as Prakrit (normal).

4. Improvement in overall nutrition.

5. Prevention or reduction in complications.

Properties of Ahara Dravyas (food items) for Grahani:-

- Deepana and Pachana Dravyas

- Laghu and Grahee (absorbent) Dravyas.

- Diet which mitigates Vata (air), Pitta (bile) and Kapha (phlegm).

- Mainly Kashaya (astringent), Madhura (sweet) and Katu (pungent) in taste.

- Typically, Grahani Rog Nashaka Dravyas (food items of choice).

\section{Choice of Ahara Dravyas:-}

The Ahara Vargas (classes), screened and selected from different Ayurvedic classics, were based on

(I) Properties (ii) Tolerance (iii) Availability of Dravyas (iv) Capacity of digestive power and (v) Predominance of the Doshas of the patient.

The Ahara Vargas are:-

- Shukadhanya Varga (Cereals)

- Shamidhanya Varga (Pulses)

- Shaka Varga (Vegetables)

- Go- ras Varga (Milk and products)

- Phala Varga (Fruits)

- Harit Varga (class of Greens)

- Aharyogi Varga (Adjuvants of foods

- Mamsa Varga (Meat) 
Table 1: Ahara Dravyas Recommended for Grahani Patients

\begin{tabular}{|c|c|c|c|c|c|}
\hline $\begin{array}{l}\text { English } \\
\text { Name] }\end{array}$ & $\begin{array}{l}\text { Sanskrit } \\
\text { Name }\end{array}$ & Rasa & Veerya & Vipaka & Guna \\
\hline Rice & Shashtika & Madhura & $\begin{array}{l}\begin{array}{l}\text { Sheeta } \\
\text { potency) }\end{array} \\
\text { cold in }\end{array}$ & Madhura & Laghu, Snigdha (unctuous) \\
\hline Green Gram & Mudga & Madhura & Sheeta & Katu & Laghu, Ruksha (creates dryness), Grahee \\
\hline Horse Gram & Kullatha & Kashaya & Ushna (hot in potency) & Katu & Laghu, Sara (mild laxative) \\
\hline Goat Curd & Chag Dadhi & Amla (sour) & Ushna & Amla & Laghu,Grahee, Deepana Butter \\
\hline Butter & Navneeta & Madhura & Sheeta & Madhura & $\begin{array}{l}\text { Grahee, Snigdha, Agnikrit (stimulates } \\
\text { Agni) }\end{array}$ \\
\hline Cow Ghee & Gavyaghrit & Madhura & Sheeta & Madhura & $\begin{array}{l}\text { Guru (difficult to digest), Rochana } \\
\text { (enhances taste perception), }\end{array}$ \\
\hline Honey & Makshika & $\begin{array}{l}\text { Madhura } \\
\text { Kashaya }\end{array}$ & Sheeta & Madhura & Laghu, Ruksha, Grahee, Deepana \\
\hline $\begin{array}{l}\text { Bengal } \\
\text { Quince, }\end{array}$ & Bilva & $\begin{array}{l}\text { Katu } \\
\text { Kashaya, }\end{array}$ & Tikta & $\begin{array}{l}\text { Ushna } \\
\text { Katu }\end{array}$ & $\begin{array}{l}\text { Laghu, Snigdha, Grahee, Deepana, } \\
\text { Pachana }\end{array}$ \\
\hline Pomegranate, & Dadima & $\begin{array}{l}\text { Kashaya } \\
\text { Madhura }\end{array}$ & Amla & Anushna & Madhura /Amla Laghu, Snigdha, Grahee \\
\hline Banana & Kadalee & Madhura & Sheeta & Madhura & Guru, Vishtambhee (restraining) \\
\hline
\end{tabular}

Also, Ayurveda has mentioned (wholesome) diet according to the Dosha predominance in Grahani as -

- Vataj - Peya (thin gruel) prepared from decoction of Panchakola. Yusha (soup) of Panchakola, Moolaka with Marich (black pepper) and Ghee

- Pittaj -Yusha of Mudga, Khada (a sour drink), added with Dadima and ghee. Jangal Mamsa (meat of animals of arid zone).

- Kaphaj - Yusha of dried Moolaka or Kullatha Yusha of Chitrak (Plumbago zeylanica) and Moolaka.

According to Sushruta drinking of Gomutra (cow urine) or Ajamutra (goat urine) early morning.

\section{DISCUSSION}

Grahani (Irritable bowel syndrome) is Amashaya Udbhava Vyadhi and its Vyakta Sthana is Guda. Grahani is Adhishtana for Agni. It has got the name Grahani because of Anna Grahana Karma. Grahani Roga described in classical textbooks of Ayurveda represents a group of disorders of digestive system caused by impairment of Agni. Grahani is such a disorder, where in its significance is emphasized by its inclusion among Ashta Maha Gadas. Various unhealthy causes' vitiation of Pitta (Agni) situated between Amashaya (stomach) and Pakwashaya (Intestine) is responsible for the manifestation of the symptoms. The Vataja Grahani Lakshanas like Punah Punah Srujet Varchah, Ama Mala, Chirat Pachana, Visuchika, Jeeye Jeeryati Adhmanam Bhukte Swasthyamupaiti has some similarities towards symptoms of Irritable Bowel Syndrome. Whereas almost all the Sangraha Grahani Lakshanas like Antrakujana, Drava Snigdha Mala, Ama Yukta Bahu Picchila Mala, Sasabda Manda Vedana, Pakshad Masad Dasadva Nityam Va, Diva Prakopo Ratrou Shanti have very good similarity with IBS. And it is also said that this disease is Durvigyeya, Dushchikitsaya, Chirakalanubandhini which is also the nature of Irritable Bowel Syndrome. But we cannot confirm that IBS is same as Grahani Roga. In Ayurveda it is said that the Psychological factors are responsible for Manovaha Sroto Dushti. This ultimately leads to Manashika \&amp; Shareerika Vyadhi. So almost all the diseases are having interlink between Shareera and Manas. As the Ayurvedic management is concerned, there is no need to correlate IBS to Ayurvedic diseases, because IBS is entirely different disease. There is only needed to 
understand the condition according to the Fundamental Principles of Ayurveda \&amp; manage cases accordingly. Education of the patient is prime important thing, with normalization of the bowel with some Shodhana and Shamana therapies accordingly. The etiological factors according to Ayurveda include regarding Ahara, Vihara and Manasika. The recent research in modern science proved that the etiological factors according to Ayurveda, act as triggering factors in the production of IBS. In Ayurvedic pathogenesis of IBS involves Prana, Samana, Apana Vata Dusti along with Pachaka Pitta \&amp; Kledaka Kapha Dusti, ultimately leads to Agnidusti, which in turn causing Doshprakopa, resulting in production of symptoms of IBS.

\section{CONCLUSION}

The 28 Ahara Dravyas of various classes can be suggested for Grahani patients. And also need to be taken for prevention of Grahani with the planning of proper diet. It is clear that, if a person takes food without the appropriate procedure, then he quickly succumbs to diseases like Irritable Bowel Syndrome caused by the vitiation of Grahani because of his uncontrolled habits. We can resume the habit of bowel to normal, improve the overall nutritional status of patients and also reduce the complications of Irritable bowel symptom with the help of Ayurvedic principles of diet.

\section{REFERENCES}

1. Agnivesh's Charaka Samhita With Ayurved Dipika, Commentary Of Chakrapanidatta, Chikitsa Sthana, Grahani Chikitsa Adhyaya 15, Edited By Dr. RK Sharma. Edition 2nd, Chaukhamba Sanskrit Series Varanasi, 2000.

2. Agnivesh's Charaka Samhita With Ayurved Dipika, Commentary Of Chakrapanidatta, Chikitsa Sthana, Grahani Chikitsa Adhyaya 15, Edited By Dr. RK Sharma, Edition 2nd, Chaukhamba Sanskrit Series, Varanasi, 2000.

3. Agnivesh's Charaka Samhita With Ayurved Dipika, Commentary Of Chakrapanidatta, Chikitsa Sthana, Grahani Chikitsa Adhyaya 15, Edited By Dr. RK Sharmaedition 2nd, Chaukhamba Sanskrit Series, Varanasi, 2000.
4. Ashtang Hridaya Of Shrimad Vagbhata, Nidana Sthana, Atisaragrahanirog Nidana Adhyaya 8, Edited By Dr. Brahmanand Tripathi, Edition Reprint, Chaukhamba Sanskrit Pratisthana, Delhi, 2012.

5. Davidson's Principles And Practices Of Medicine, Edition 20th, Churchill Livingstone, Elsevier, 2006.

6. Agnivesh's Charaka Samhita With Ayurved Dipika, Commentary Of Chakrapanidatta, Chikitsa Sthana, Grahani Chikitsa Adhyaya 15, Edited By Dr. RK Sharma, Edition 2nd, Chaukhamba Sanskrit Series, Varanasi, 2000.

7. Agnivesh's Charaka Samhita With Ayurved Dipika, Commentary Of Chakrapanidatta, Chikitsa Sthana, Grahani Chikitsa Adhyaya 15, Edited By Dr. RK Sharma., Edition 2nd, Chaukhamba Sanskrit Series, Varanasi, 2000.

8. Bhavprakasha Nighantu Of Shri Bhavmishra, Purvakhanda, Mishraprakarana, Dhanyavarga 9, Edited By Prof. KC Chunekar, Edition Revised, Chaukhamba Bharati Academy, Varanasi, 2010.

9. Bhavprakasha Nighantu Of Shri Bhavmishra, Purvakhanda, Mishraprakarana, Dhanyavarga, Edited By Prof. KC Chunekar, Edition Revised, Chaukhamba Bharati Academy, Varanasi, 2010.

10. Bhavprakasha Nighantu Of Shri Bhavmishra, Purvakhanda, Mishraprakarana, Dhanyavarga, Edited By Prof. KC Chunekar, Edition Revised, Chaukhamba Bharati Academy, Varanasi, 2010.

11. Bhavprakasha Nighantu Of Shri Bhavmishra, Purvakhanda, Mishraprakarana, Dadhivarga, Edited By Prof. KC Chunekar, Edition Revised, Chaukhamba Bharati Academy, Varanasi, 2010.

12. Bhavprakasha Nighantu Of Shri Bhavmishra, Purvakhanda, Mishraprakarana, Dhanyavarga, Edited By Prof. KC Chunekar, Edition Revised, Chaukhamba Bharati Academy, Varanasi, 2010.

\section{Source of Support: Nil \\ Conflict of Interest: None Declared}

How to cite this URL: Khushboo Bhardwaj et al: A Review Article On Diet In Grahani Roga. International Ayurvedic Medical Journal \{online\} 2020 \{cited December, 2020\} Available from: http://www.iamj.in/posts/images/upload/5395 5398.pdf 